\title{
Reducing income inequality in Europe
}

\author{
Anthony Barnes Atkinson
}

Correspondence:

tony.atkinson@nuffield.ox.ac.uk Nuffield College, Oxford OX1 1NF, UK

\begin{abstract}
World leaders have come to recognise the challenge posed by high and rising economic inequality. This paper asks how Europe can address excessive inequality. It argues that we should learn from the lessons of history; there have been significant periods in the past when inequality fell. We can make use of economic analysis, drawing on both recent and older literatures. Inequality arises not only between skilled and unskilled workers, but also between labour and capital. In seeking solutions, we should go beyond the options currently prominent in public debate and be willing to think "outside the box".

JEL codes: D31, D63 and J31

Keywords: Inequality wages capital redistribution
\end{abstract}

\section{Introduction}

In her speech to the 2013 Davos meeting, Christine Lagarde quoted Franklin Roosevelt as saying that "the test of our progress is not whether we add more to the abundance of those who have much; it is whether we provide enough for those who have too little". She went on to say

"I was not surprised, therefore, to see that the World Economic Forum's most recent survey puts "severe income disparity" at the very top of global risks over the next decade. Excessive inequality is corrosive to growth; it is corrosive to society. I believe that the economics profession and the policy community have downplayed inequality for too long. Now all of us-including the IMF-have a better understanding that a more equal distribution of income allows for more economic stability, more sustained economic growth, and healthier societies with stronger bonds of cohesion and trust. The research reaffirms this finding. What is less clear is how we achieve more inclusive growth in practice".

The aim of this paper is to consider how Europe could reduce excessive income inequality. It suggests three approaches:

- Learning from history;

- Learning from economic analysis;

- Drawing policy ideas from outside the box. 
In discussing these issues my primary focus is on inequality within countries, but I return at the end to world inequality.

\section{Learning from history}

Income inequality in most, but not all, OECD countries is significantly higher than thirty years ago (Atkinson, 2013a). The EU as a whole has failed to make a significant reduction in the proportion of its citizens living at risk of poverty. Top income shares are racing away in many countries. However, it has not always been so. We tend to focus on recent decades, but we can learn from earlier periods when inequality fell. The downward section of the Kuznets curve did really exist. It is for this reason that, together with colleagues, I have invested much time in studying the long-run development of inequality (see, for example, the World Top Incomes Database, and Atkinson and Morelli, 2013).

The long-run picture shows that history is not dominated by secular trends, but rather by distinct episodes. In the case of the UK, this is illustrated in Figure 1, which shows the dispersion of individual earnings, measured by the top and bottom deciles, expressed as percentages of the median, over nearly sixty years. There are four distinct phases. In the first and the third phases, dispersion is unambiguously widening; in the most recent the top has been rising at the same rate as in phases 1 and 3, but the bottom decile has not fallen relative to the median. And there was phase 2: the period of the second half of the 1960s and 1970s when the bottom decile rose from around 45 per cent of the median to over 55 per cent, and the top decile fell from 175 per cent to 165 per cent.

If we turn to the distribution of household disposable income, we see that there have been salient falls in the Gini coefficient. As a guide to thinking about "salience", I use a criterion of a 3 percentage points fall. To achieve such a fall via a linear tax would require 5 percentage point increase in the marginal tax rate (where government real spending is 20 per cent of total income and the pre-redistribution Gini is 48 per cent).

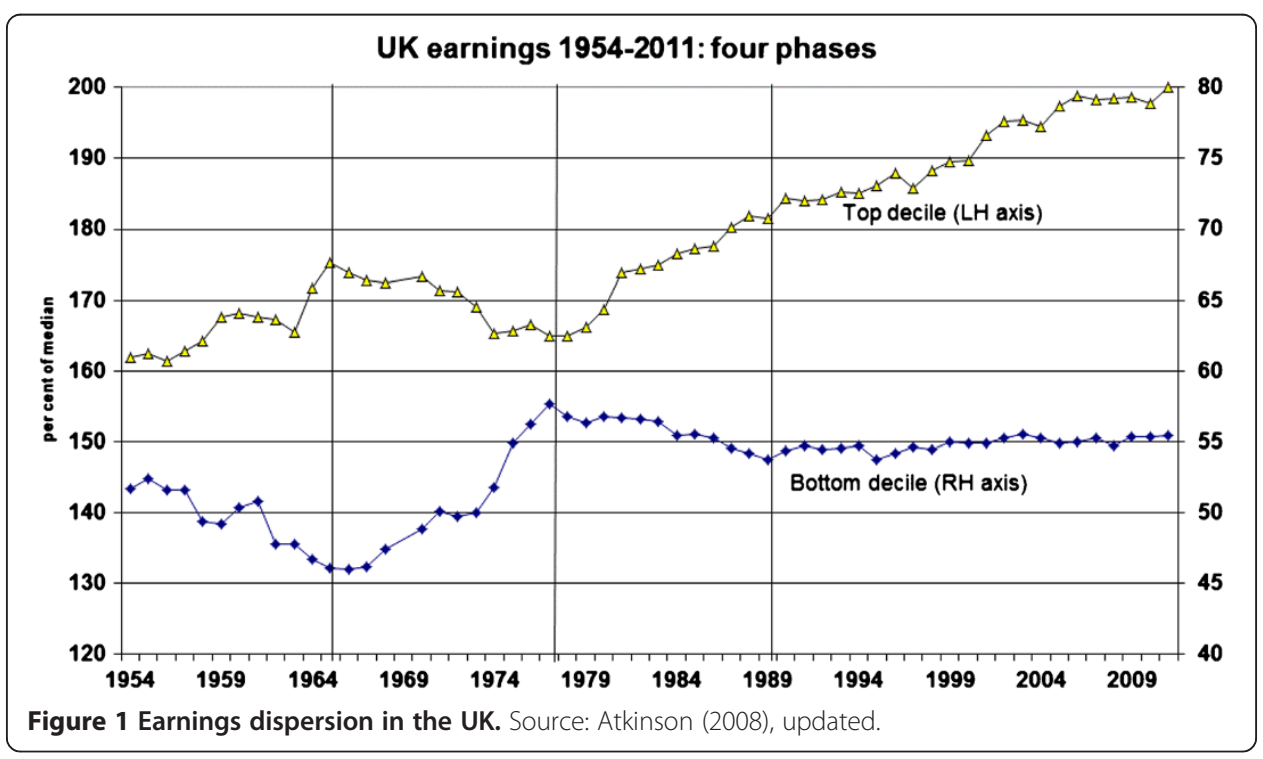


A 5 percentage point increase in taxation would certainly be treated as a major political challenge by any minister of finance.

From Figure 2, we can see that salient - indeed large - falls were achieved in the Nordic countries in the later 1960s and 1970s - broadly the same period as the fall in earnings dispersion in the UK. The Gini coefficients fell by some 10 percentage points in Denmark and Finland, making them among the least unequal countries in the world. The fall in Sweden was some 5 percentage points. In the same way, Figure 3 shows more than salient falls in the countries of Continental Europe. In France and Italy, the decrease - from quite a high level - was again some 10 percentage points; in Germany and the Netherlands, it was more than 5 percentage points. (Figure 3 also shows the salient increase in the Gini coefficient in Germany that has taken place in the past decade.)

How were these reductions in inequality brought about? In part, they were the product of tax and transfer policy. At this time, all the countries concerned operated highly progressive personal income taxes. There were progressive taxes on wealth, or on the transfer of wealth via inheritance. It was the time of the expansion of the welfare state, which meant that the safety net became more effective and that those at the bottom of the income distribution were able to share in rising prosperity.

Since then, many countries have scaled back their redistributive ambitions. In the United Kingdom, National Insurance in the 1960s provided earnings-related unemployment benefits for six months and flat-rate benefit for a further six months. The earnings-related benefit scheme was abolished in the 1980s. Child benefit when introduced in the 1970s was some 18 per cent of mean gross income for a family with 2 children; today it is only 10 per cent. The UK is not alone. Other OECD countries have seen major cuts in their tax-transfer programmes, such as the Hartz IV measures in Germany. This general trend has been documented by the OECD in their reports Growing Unequal? (OECD, 2008) and Divided We Stand OECD, 2011). As summarised

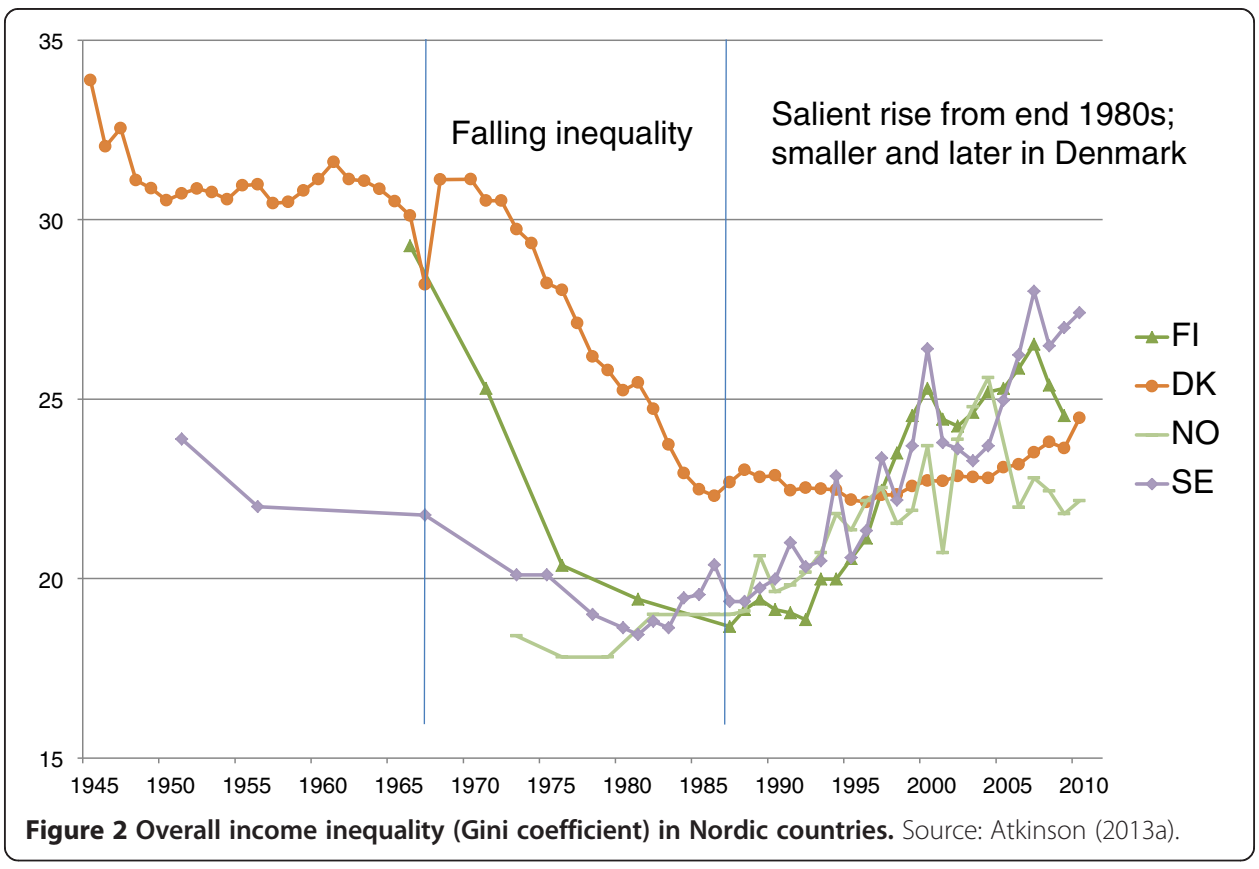




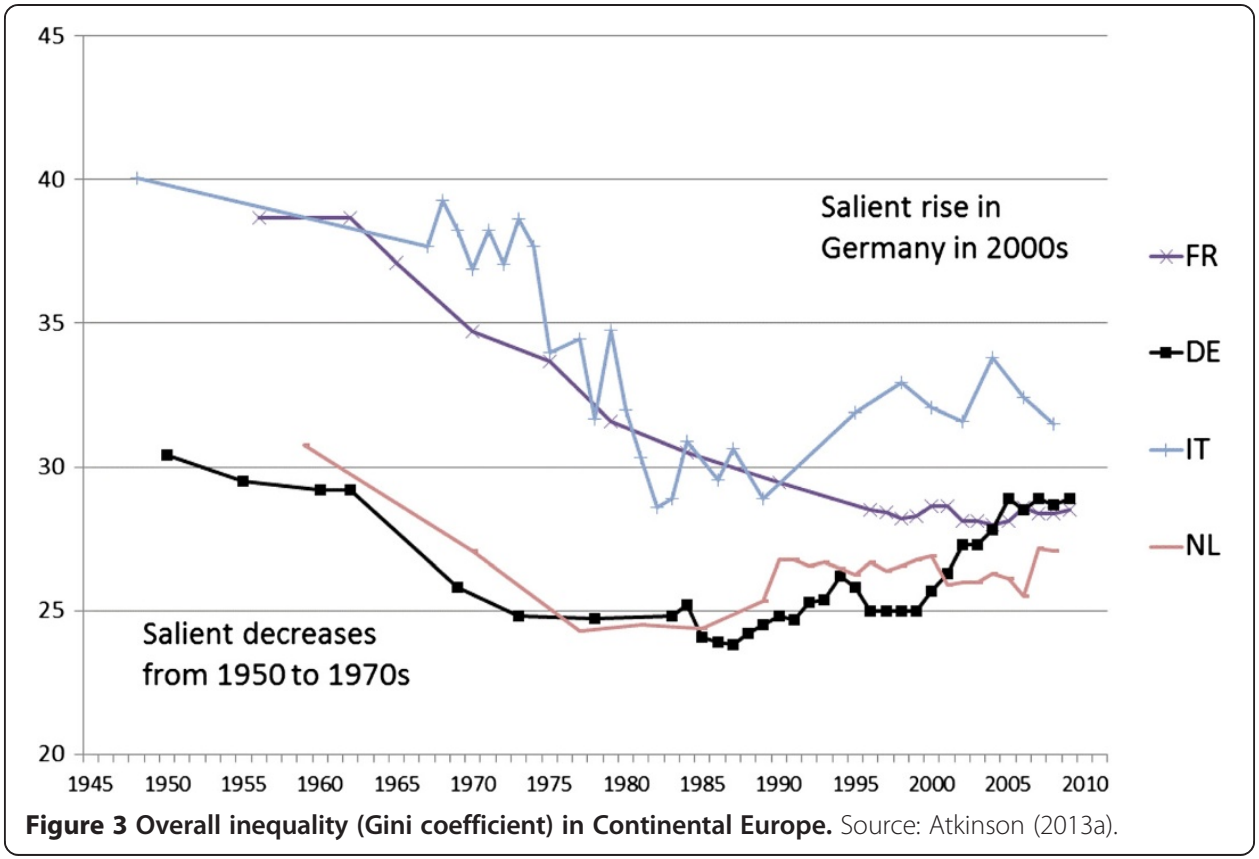

by the Secretary-General of OECD, "from the mid-1990s ... the reduced redistributive capacity of tax-benefit systems was sometimes the main source of widening householdincome gaps" (OECD, 2011).

The post-war reductions in inequality were not only achieved by redistribution. Significant measures were taken to change the pre-tax and transfer distribution. These included labour market interventions, not least those in response to the increased participation of women in the labour force. In the case of the UK, for example, the narrowing of the earnings distribution in the 1970s was in part the result of the laws governing equal pay for men and women. In many countries there were minimum wages, governed by legislation, or effected via collective bargaining.

There was intervention in the capital market. Capital markets were highly regulated. Such a situation may now be regarded as anachronistic; however it is worth remembering that it also contributed to ensuring financial stability. In our study of financial crises in 25 countries, Salvatore Morelli and I found that in the period 1945 to 1980, there were only 3 crises in these countries, whereas since 1980 there have been 24 crises, such as the Nordic financial crises of the early 1990s. It was also the case that many governments were engaged in re-building their balance sheets. In 1957, the net worth of the UK public sector was negative, minus 40 per cent of national income; by 1979 this had become positive and equal to 140 per cent of national income. The state had a stake in the productive wealth of the economy, including the direct ownership of shares, such as a 51 per cent stake in BP.

Finally, when talking of anachronistic policies, it should be recalled that the 1960s and 1970s were the period of incomes policies, some of which were explicitly redistributive. When I was a student at Cambridge, my teachers were actively engaged in the design of such policies, and incomes policies seemed a natural part of the policy armoury, but today they are largely forgotten. To obtain a modern perspective, I checked Wikipedia, according to which: 
"During the French Revolution, "The Law of the Maximum" imposed price controls (by penalty of death) in an unsuccessful attempt to curb inflation, and such measures were also attempted after World War II. Peacetime income policies were resorted to in the USA in August 1971 [under President Nixon] as a response to inflation. The wage and price controls were effective initially but were made less restrictive in January 1973, and later removed when they seemed to be having no effect on curbing inflation. Incomes policies were successful in the United Kingdom during World War II but less successful in the post-war era. Experience was mixed but somewhat more favourable in countries such as Australia and the Netherlands".

Parts of this history are alarming, but we should perhaps look again at the possible function of incomes policies, particularly in the context of fiscal consolidation measures, where there may be renewed interest in tax-based incomes policies.

\section{Learning from economic analysis}

We can learn not only from history but also from economic analysis. Christine Lagarde criticised the economics profession for having neglected the economics of inequality, but they have not totally ignored the subject. Indeed, the 1980s saw the launching of a large literature in the field of labour economics concerning the widening wage distribution. Hundreds of articles have been written on this subject, and there is now a standard story. Open virtually any introductory economics textbook and you will find an explanation of rising income inequality in terms of supply and demand. The explanation was originally due to the Dutch economist, Jan Tinbergen, who talked in the 1970s about the race between technology, raising the demand for skilled workers, and education, increasing the supply. If, he argued, demand rose faster, then the relative earnings of skilled workers would rise, and vice versa. Since he wrote, a further factor has been introduced: globalisation. The increased supply of goods on the world market from countries with lower wage costs has driven down the relative price of goods in which unskilled workers are more intensively engaged, and hence widened the wage differential.

The outcome of the race depends on the supply response, which is crucial. If the supply of skilled labour does not react, then wage dispersion will go on rising, but it seems highly improbable that there will be no supply response. In an open economy, there will be inward migration of skilled workers, and in all economies the increased skill premium provides an incentive for the acquisition of skills. If we take a simple human capital view, which is that people will seek training where the wage differential for educated work is sufficient to offset the cost of training, then an infinite speed of response would mean that the wage differential did not move from that required to repay the cost of education. In the more likely intermediate case, where supply responds gradually according to the excess of the skilled wage over the cost of becoming skilled, then a continued shift in demand leads to a rising wage premium, but one that eventually levels-off. (The dynamics are set out in Atkinson, 2008.)

Such a theoretical framework has immediate policy implications. The size of the permanent increase in the wage premium depends on the rate of demand shift, broadly common across OECD countries, but also on the speed of adjustment, which varies from country to country according to their institutions and the policies adopted. Hence 
the emphasis on education and training that recurs in European policy agendas. But there is also a less discussed aspect. The wage premium may also have increased because of rise in the effective cost of borrowing to fund education, which points to policies to reduce costs of training and education. This in turn implies an inter-connection between the labour market and the capital market, to which I now turn.

The textbook account of rising wage dispersion focuses on the roles of skilled and unskilled workers. Aggregate output is a function of $\mathrm{L}_{S}$ and $\mathrm{L}_{\mathrm{U}}$. Yet when I go back to a book that I read in 1964 when I was a student - Efficiency, Equality and the Ownership of Property - by James Meade (1964), I find a fascinating treatment of technological change - referred to as "automation" - in terms of the impact on capital and labour. For Meade, output was a function of $\mathrm{K}$ and L. It seems to me that these two strands should be combined. Output should be seen as a function of $\mathrm{L}_{\mathrm{S}}, \mathrm{L}_{\mathrm{U}}$ and $\mathrm{K}$. This is important, since the share of capital in national income appears to be rising in many OECD countries. Before the crisis, the IMF noted that "over the past two decades, there has been a continued decline in the share of income that accrues to labor, especially in Europe and Japan" (International Monetary Fund IMF 2007, page 168). The European Commission equally reported that

"The part of added value allocated to labour reached a historically low level in 2006. This trend is in particular the result of technological progress and globalisation. It may have a negative impact on social equity, economic efficiency and macro-economic stability" (Summary of chapter in Employment in Europe 2007, European Commission 2007).

According to the 2012 Employment Outlook of the OECD 2012, "in recent decades, the labour share, or the share of labour compensation (wage, salaries and benefits) in the total national income, has been declining in almost all OECD countries. The median labour share dropped to $61.7 \%$ in the late 2000 s, from $66.1 \%$ in the early 1990 s and in some countries this decline began over 30 years ago".

Perceived in terms of three, rather than two, factors of production, the issues of technical change and globalisation take on a different form, as has been highlighted in the recent US discussion of firms moving production back to the United States as a result of the spread of robotisation (Krugman, 2012). This may change the employment dynamic. In the past, it has been argued that it is semi-skilled production jobs that have been shipped abroad to lower wage countries, but that unskilled service sector jobs could not be so outsourced. This has led to job polarisation, with employment growth at both ends of the scale. Personal services have to be performed domestically. We have to ask, however, whether this will continue. With increased robotisation, unskilled service jobs may over time offer less employment. If my neighbour has a robot to mow his lawn (as he does), then he no longer needs a gardener. Technical change may well be benefiting capital at the expenses of workers as a whole.

What are the distributional implications of a rising profit share? Is it not the case that the capitalists of the past have been replaced by institutional shareholders, with the ultimate beneficiaries from an increased profit share being households (for example in the form of private pensions)? The indirect ownership of shares has certainly increased, but it has been accompanied by the development of financial intermediaries with funds 
under their management. Recourse to private pensions and increased savings for old age are one of the major drivers of the growth of the financial services industry. A significant proportion of increased profits goes therefore not to the ultimate holders but in management fees and other payments for financial services. In the UK, household spending on financial services rose in volume terms by 20 per cent between 2003 and 2011, compared with 6 per cent increase in total household consumer spending (Office for National Statistics, 2012, Table 6.5).

\section{Drawing policy ideas from outside the box}

In choosing this title for the section, I am not suggesting that the standard policy prescriptions are without value. It is right that Europe, faced with the twin challenges posed by globalization and technological change, should emphasise education and the up-skilling of the labour force. "Smart growth" makes sense. In the same way, I support calls for a return to a more redistributive tax and transfer policy. Rises in top income tax rates, or the introduction of a luxury rate of VAT, can contribute to fiscal consolidation and help ensure that the burden of fiscal adjustment can be more fairly shared. But I also believe that we need to look beyond the options currently prominent in public debate, and be willing to "think outside the box". The proposals sketched in this section may immediately be dismissed as politically infeasible; however, I would like to urge that they be given serious consideration.

The policies are grouped at the national level, the EU level, and the global level, with two under each head.

\section{National policies}

One of the lessons of the economic crisis is that the determination of pay is not a matter from which governments can stand aloof. Citizens have become increasingly aware of the fact that pay is not simply a product of market forces but that it is influenced by institutions and social norms that govern the behaviour of workers and employers. The job search model now standard in the macro-economic literature makes clear that any job match generates a "surplus" which has to be shared between the two sides. In the lower ranges of earnings, the decline in the strength of trade unions has reduced their bargaining power. At the other end of the scale, the rise in top earnings reflects the fact that the surplus is larger - on account of technology and global reach - but also that the division of the surplus is increasingly being tilted in favour of top earners. Such a tilt may result from increased bargaining power, with executives attaching more weight to pecuniary rewards (a development that may in turn be explained by the reductions in top tax rates). The tilt may also result from changing social norms, with top earners are exercising less "restraint" than in the past.

In this context, national governments can influence the distribution of earnings. This could take the form of enhanced minimum wage legislation, to tackle the problem of "in work poverty". It could be a lighter touch exercise of moral suasion, as in some incomes policies in the past, coupled with publicity concerning the extent of pay differentials. In between, in degree of intervention, would be the use of government purchasing power to insist on fair pay practices by private contractors, coupled with the active use of shareholdings in companies part or wholly owned by the state. 
Inequality is not only about pay. National governments should also give serious consideration to the ownership of capital, and specifically to schemes for asset-based egalitarianism (see Ackerman and Alstott, 1999). In the United Kingdom, such a scheme was enacted in 2004 in the form of child trust funds, which were a vehicle for saving tax free with a contribution paid by the government. (The funds were abolished by the Coalition Government on coming to office.) The idea is however an old one. Thomas Paine in 1797 in his Agrarian Justice proposed: ${ }^{1}$

"To create a national fund, out of which there shall be paid to every person, when arrived at the age of twenty-one years, the sum of fifteen pounds sterling, as a compensation in part, for the loss of his or her natural inheritance, by the introduction of the system of landed property" (Paine, 1797).

To fund it, he favoured taxing inheritance, and it seems important today to reconsider the role of inheritance taxation. Historically, the taxation of wealth transfers was an important source of tax revenues. In the United Kingdom, in the 1930s, a higher proportion of the population were taxed on their estates at death than typically paid income tax on their incomes in any one year. The role of inheritance declined over the twentieth century, but there are signs that it is returning in importance. In France, we have seen a significant rise in the amount of wealth passing from one generation to another, with a particular role played by gifts inter vivos (Piketty 2011). This evidence of the return of inheritance points to the re-establishment of effective taxation on lifetime wealth transfers received, based on the (indexed) total amount received in bequests and gifts over the lifetime. Calling it a lifetime capital receipts tax, rather than a transfer tax, would emphasise the aspect at which the tax is directed - the transmission of unearned advantage.

\section{EU-wide policies}

In this section I consider two proposals that are radical, but not outlandish. Both are in fact discussed in the recent report on Employment and Social Developments in Europe (European Commission, 2012). The first proposal is for an EU-wide unemployment benefit. This is far from a new idea, having been proposed - without success - by the Marjolin Report in and supported by the MacDougall Report in 1978. The latter saw such a step as an important aid to the operation of monetary union:

"Apart from the political attractions of bringing the individual citizen into direct contact with the Community, it would have significant redistributive effects and help to cushion temporary setbacks in particular member countries, thereby going a small part of the way towards creating a situation in which monetary union could be sustained" (MacDougall and chair 1977, page 16).

Fast forwarding a third of a century, the proposal has been put back on the table in the report to the December 2012 European Council Meeting on the Roadmap Towards a Genuine Economic and Monetary Union (Van Rompuy, 2012) (see, for more details, Andor (2012)). 
What would an EU-wide unemployment benefit mean? What would be the relation with existing national systems of unemployment benefit? It is assumed that Member States would be expected to maintain their national benefit systems: i.e. they would not simply reduce their national benefits by the amount of the EU-benefit. The most straightforward EU scheme could take the form of extending the duration of unemployment insurance beyond the current national limits. As such it would closely parallel the federal extended Unemployment Insurance benefits in the United States. When unemployment reaches a threshold level, US states are required by federal law to extend benefits. In 2013, under the Emergency Compensation Program, benefits are paid according to a tiered scale: for example, up to 54 weeks where the state unemployment rate is 6 per cent or higher, reaching a maximum of 73 weeks where the unemployment rate is 9 per cent or higher. Extended unemployment insurance would in itself help address the problem of benefit exhaustion in national schemes, but other aspects would require action on the other benefit conditions. Here the EU scheme could, more ambitiously, seek to harmonise conditions such as those regarding "voluntary entry" into unemployment, availability for work, and refusal of job offers. An alternative would be to re-open the idea of a $\mathrm{X}+1$ th state, under which the EU would constitute itself as an additional state providing an autonomous social security system. ${ }^{2}$ Initially envisaged for migrant workers, for whom it could be either voluntary or compulsory, a European Social Security System could be opened on a voluntary basis to all EU citizens. As such, it would provide a benchmark for national systems.

Our aspirations for reform of EU social protection should not however be limited to unemployment benefit and we need to consider new forms of social security. Of these, perhaps the most discussed is the idea of a "citizen's income or a "basic income", whereby a universal benefit is paid individually to all citizens, varying across Member States according to their circumstances. Again this is an old idea, but - with one exception - has not been adopted as part of European social protection. At a national level, it has typically been most discussed at times of reconstruction, such as after the Second World War, and in that sense it may be a natural idea for the EU to consider as part of a major "leap forward". It does however raise the issue of the basis for eligibility. While a basic income is often described as "unconditional", there has to be a qualifying condition. This is usually taken to be citizenship, but citizenship is not the same as the basis for taxation nor is it evidently the right basis in an EU labour market. Citizenship would mean that a Swedish worker in France would receive the Swedish basic income, not the French basic income. The rationale for a basic income that varies across countries is that the basic income should vary with the cost of participating in a particular society. An alternative approach therefore is to make the basic income conditional, not on citizenship, but on participation in society. "Participation" could be defined broadly in terms of social contribution, which for those of working age could be fulfilled by full- or part-time waged employment or self-employment, by education, training or active job search, by home care for infant children or frail elderly people, or by regular voluntary work in a recognised association. It should be noted that the qualifying nonmarket activities would require validation.

The exception to the statement that a basic income had not yet entered European social protection concerns child benefit. The payment of a universal benefit for all children, perhaps varying by age, can be seen as a specific form of basic income. Such 
payments are common in $\mathrm{EU}$ countries. If the $\mathrm{EU}$ is to go down the basic income route, then a natural starting point is with an EU basic income for children. Some ten years ago, the High-Level Group on the future of social policy in an enlarged European Union (European Commission, 2004) made such a proposal, as part of a possible "inter-generational pact". In concrete terms, this could mean an EU-wide basic income for children, set, say, at 10 per cent of median income per capita in each Member State for each child, administered and financed by each Member State. Such a programme - refined in its details - would allow the EU to invest in its future - children and human capital.

\section{Global policies}

A natural reaction to my earlier discussion of progressive taxation, such as raising top income tax rates, is that the world is very different from the 1950s and 1960s. Today a nation state is limited by global fiscal competition. This is clearly the case, but it does not imply fiscal impotence. Rather it points to the need for a global tax institution. This cannot be called a World Tax Organisation, but could - provided the Women's Tennis Association agrees - be called a World Tax Authority.

Such a WTA should have a two-fold mandate. The first, and immediate, task is the co-ordination of national tax regimes, allowing the effective enforcement of national tax policies. The second is the administration of taxes on a many-nation, ultimately global, basis. The establishment of "global taxes" may appear totally unrealistic. There are however reasons to suppose that we are, slowly, moving in that direction. Recent years have seen significant steps towards the exchange of information and steps to close down tax havens. Public opinion has moved decisively against unprincipled tax avoidance. The EU moves towards a financial transactions tax suggests that flexible geometry works.

Finally, I have focused on rich countries and on inequality within countries. We cannot however ignore the interdependencies between countries. The policies pursued by OECD countries and by the EU have consequences for the rest of the world. If production is repatriated from Asia to the US, then this reduces the employment prospects of Asian workers. Nor can we ignore the fact that 2015 - the date for achieving the Millennium Development Goals - is rapidly approaching. Even if in total some of the key targets are being achieved, the success is not uniformly shared among developing countries. Brazil is on target to meet many of the goals; Benin is unlikely to meet any. Even if the number of people living below $\$ 1.25$ a day is halved, that still leaves a major problem of world poverty after 2015. The United Nations needs to set an ambitious agenda for the next 15 years.

\section{Conclusions}

Ever -increasing income inequality is not inevitable. The recent rise is due not only to technology and globalisation but reflects the institutions and policies adopted in the labour and capital markets. National governments are not powerless to take measures to reduce excessive inequality; there are concrete steps that can be taken by European Union. 


\section{Endnotes}

${ }^{1}$ The text can be downloaded from the Official Website of the U.S. Social Security Administration. The website carries the caution: "this is an archival or historical document and may not reflect current policies or procedures".

${ }^{2}$ This idea was put forward by Danny Pieters. In the field of pensions, Mario Monti in his 2010 report on the Single Market proposed "a 28th regime for supplementary pension rights. This would be a regime entirely set by EU rules but existing in parallel to national rules, and thus optional for companies and workers. A worker opting for this regime would be subject to the same rules for its non statutory benefits wherever it goes in Europe" (Monti, 2010, page 58).

\section{Competing interests}

The IZA Journal of European Labor Studies is committed to the IZA Guiding Principles of Research Integrity. The author declares that he has observed these principles.

\section{Acknowledgements}

I am grateful to the referees for helpful suggestions. The research reported here forms part of the Inequality project at INET@OxfordMartinSchool, and I have drawn in particular on the Chartbook of Economic Inequality, prepared jointly with Salvatore Morelli, and available at http://ineteconomics.org/research_note/chartbook-economic-inequality-25countries-1911-2010. I have also drawn on a paper prepared while holding a Fellowship at DG ECFIN of the European Commission (Atkinson, 2013b)

Responsible editor: Martin Kahanec

Received: 24 July 2013 Accepted: 6 September 2013

Published: 23 September 2013

\section{References}

Ackerman B, Alstott A (1999) The stake-holder society. Yale University Press, New Haven

Andor L (2012) "What does more Europe mean?", speech to Friends of Europe 9th Annual VIP round table, "State of Europe: Escaping the doldrums". Europa Press Release, 11 October 2012, European Comission, Brussels

Atkinson AB (2008) The changing distribution of earnings in OECD countries. Oxford University Press, Oxford

Atkinson AB (2013a) Where is inequality headed? Arrow Lecture, Stanford University, Stanford

Atkinson AB (2013b) "Ensuring social inclusion in changing labour and capital markets", paper prepared for DG ECFIN. European Economy Economic Paper 481, Economic and Financial Affairs, European commission, Brussels

Atkinson AB, Morelli S (2013) A Chartbook of Economic Inequality. http://ineteconomics.org/research_note/chartbookeconomic-inequality-25-countries-1911-2010

European Commission (2004) Report of the high-level group on the future of social policy in an enlarged European Union. Office for Official Publications of the European Communities, Luxembourg

European Commission (2007) The Labour Income Share in the European Union in Employment in Europe 2007. European Commission, Brussels

European Commission (2012) Employment and social developments in Europe 2012. Publications Office of the European Union, Luxembourg

International Monetary Fund (IMF) (2007) World Economic Outlook, April., Washington, DC

Krugman P (2012) Robots and robber barons. The New York Times, 09 December 2012, New York

MacDougall D, chair (1977) Report of the Study Group on the role of public finance in European integration. European Commission, Brussels

Meade JE (1964) Efficiency, equality and the ownership of property. Allen and Unwin, London

Monti M (2010) A new strategy for the Single Market. Report to the President of the European Commission. European Commission, Brussels

OECD (2008) Growing unequal? OECD, Paris

OECD (2011) Divided we stand. OECD, Paris

OECD (2012) Employment outlook. OECD, Paris

Office for National Statistics, 2012, United Kingdon National Accounts, Office for National Statistics, Newport Paine T (1797) Agrarian justice. Digital edition, 1997, grundskyld.dk. Robert Schalkenbach Foundation, New York Piketty T (2011) On the long-run evolution of inheritance: France 1820-2050. Quarterly Journal of Economics 126:1071-1131 Van Rompuy HA (2012) Towards a genuine economic and monetary union. European Council, Brussels

doi:10.1186/2193-9012-2-12

Cite this article as: Atkinson: Reducing income inequality in Europe. IZA Journal of European Labor Studies $20132: 12$. 